\title{
Caracterización petrofísica de tres variedades comerciales de areniscas miocenas del valle del Ebro
}

\section{Petrophysical characterization of three commercial varieties of miocene sandstones from the Ebro valley}

\author{
$\underline{\text { O. Buj }}^{(*)}$ y $\underline{\text { J. Gisbert }}^{(*)}$
}

Recepción/Received: 7-III-06

Aceptación/Accepted: 17-I-07

RESUMEN

Las areniscas miocenas estudiadas han sido y son ampliamente utilizadas en patrimonio histórico y en obra civil moderna, localizándose las canteras actuales en el borde de la depresión del Ebro. Se ha realizado un exhaustivo estudio de las características petrofísicas de estos materiales, que pese a presentar la misma edad y pertenecer a la misma cuenca sedimentaria presentan características mineralógicas y texturales diferentes que les confieren diferentes propiedades físicas, mecánicas y una diferente durabilidad. Las características petrográficas y petrofísicas se han evaluado mediante la realización de ensayos según las normas UNE, NORMAL y ASTM. Para todos los ensayos se ha realizado un tratamiento estadístico de los resultados para evaluar las posibles inhomogeneidades texturales y composicionales presentes en el material y que pueden originar modificaciones en su comportamiento.

Los resultados ponen de manifiesto que estas areniscas presentan un importante valor industrial como materiales de usos constructivos, siendo la arenisca de Alcañiz la que presenta una mayor durabilidad como consecuencia de la configuración de su sistema poroso.

Palabras clave: arenisca, propiedades físicas, durabilidad, petrofísica, piedra de construcción.
SUMMARY

Miocene sandstones studied were used extensively to build Aragon's architectural heritage, are still used in modern construction. The quarries presently located on the edge of the Ebro Valley depression. The present paper describes an exhaustive petrophysical study of these materials, which while, of the same age and from the same deposition basin, exhibit different mineralogical and textural characteristics and as a result, different physical and mechanical properties and durability. The petrographic and petrophysical characteristics of these materials were evaluated with tests prescribed in UNE (Spanish), NORMAL and ASTM standards. All the results were subjected to statistical analysis to identify possible textural and compositional nonuniformities in the material that may underlie behavioural changes.

The results of the present paper show that their petrophysical characteristics afford these sandstones substantial industrial value as construction materials. Durability was found to be longest in the Alcañiz stone, as a result of the geometry of its pore network.

Keywords: sandstone, physical properties, durability, petrophysics, construction stone.

(*) Universidad de Zaragoza (Zaragoza, España).

Persona de contacto/Corresponding author: oscarbuj@unizar.es, gisbert@unizar.es 


\section{INTRODUCCIÓN}

Las areniscas miocenas de Uncastillo, Ayerbe y Alcañiz se localizan en el borde exterior del sector central de la depresión terciaria del Ebro. Estos materiales han sido ampliamente utilizados a lo largo de los siglos para la construcción en obras que han dejado una particular impronta en el variado patrimonio cultural y monumental aragonés. Entre otros, son ejemplos de la utilización de la Piedra de Uncastillo, el yacimiento arqueológico de los Bañales (siglo I d.C.), el Mausoleo de los Atilios (monumento funerario del siglo II d.C.) y el castillo de Sádaba (siglo XIII). La Piedra de Ayerbe ha sido utilizada en el castillo de Loarre (siglo XI) y en la catedral de Huesca (Siglo XIII), mientras que la Piedra de Alcañiz ha sido utilizada en el castillo Alcañiz (siglo XII) y en la casa consistorial de Alcañiz (siglo XVI). En la actualidad se explotan como piedras de cantería (producción anual aproximada de 20.000 T) y su valor se debe tanto a sus reservas y propiedades físicas y mecánicas como a su facilidad de labra.

Desde el punto de vista geológico, las tres areniscas pertenecen a facies detríticas del terciario medio-superior de la cuenca del Ebro, siendo interpretadas como sedimentos fluviales de sistemas aluviales con regímenes variados, pero predominantemente meandriformes que gradan hacia sistemas lacustres (1).

La variedad de litotipos existentes está controlada por las facies sedimentológicas y por el grado de alteración de la roca. La arenisca de Uncastillo presenta una variabilidad litológica condicionada por el espesor de los estratos (1,2$3 \mathrm{~m}$ ) y por su grado de alteración. En el caso de la arenisca Ayerbe existe una única cantera fija que explota 3-4 niveles del mismo litotipo por debajo del nivel de alteración. La arenisca de Alcañiz es explotada en varias canteras en un área relativamente extensa que abarca desde Vinaixa (Lérida) hasta Alcañiz (Teruel). Las canteras más nororientales (Vinaixa) poseen una composición más carbonatada $92,8 \%$ (2) y las próximas a Alcañiz, aun dominando el carbonato, poseen composiciones más silicatadas. La relación entre clastos carbonatados y siliciclásticos determina la calidad petrofísica de la roca, correspondiendo la arenisca aquí estudiada a la familia composicional $\mathrm{Q}_{2} \mathrm{BT}$ (3-4).

Las areniscas de Uncastillo y Ayerbe pertenecen a la Fm Uncastillo, de edad Mioceno inferior (Aquitaniense - Burdigaliense) (5), que se encuadra en el norte de la depresión del Ebro y en contacto con las sierras exteriores. Está constituida por una alternancia de arcillas y areniscas que se presentan en forma de cordones sinuosos aislados y, ocasionalmente, en forma de placas depositadas a partir de abanicos aluviales y fluviales procedentes de las sierras exteriores.

La arenisca de Uncastillo estudiada se explota en la cantera Martínez a partir de estratos subhorizontales

\section{INTRODUCTION}

Uncastillo, Ayerbe and Alcañiz Miocene sandstones are located on the outer edge of the central sector of the Ebro Valley Tertiary depression. These materials can be identified in many of the structures that have left a distinctive imprint on Aragon's varied cultural and monumental heritage. Examples of Uncastillo stone are to be found, among others, at Bañales archaeological site (first century CE), Atilios Mausoleum (2 ${ }^{\text {nd }}$ century CE funeral monument) and Sádaba Castle (13 th century). Ayerbe stone was used in Loarre Castle (11 th century) and Huesca Cathedral (13 th century), while Alcañiz stone is found in Alcañiz Castle (12 ${ }^{\text {th }}$ century) and Alcañiz Town Hall (16 ${ }^{\text {th }}$ century). These materials, which are still being quarried (yearly output of around 20,000 t), are presently valued for both their physical and mechanical properties and the ease with which they can be worked.

Geologically speaking, the three sandstones consist in detrital facies from the Mid-Upper Tertiary Ebro basin, and are interpreted to be fluvial depositions in alluvial fans characterized by varying, although predominantly meandering, flows evolving into lacustrine systems (1).

The variety of stone types in this outcrop depends on the depositional facies and the degree of rock alteration. The variability of Uncastillo sandstone is conditioned by stratum thickness (1.2-3 $\mathrm{m}$ ) and degree of alteration. Ayerbe stone is taken from a single permanent quarry where 3-4 benches of the same stone type, all underneath the alteration level, are worked. Alcañiz stone is quarried at various sites over a fairly large area stretching from Vinaixa in the province of Lleida to Alcañiz in the province of Teruel. The stone from the most northeasterly of these quarries (Vinaixa) has a higher carbonate content (92.8\%) (2), whereas the rock in the vicinity of Alcañiz, in which carbonate also prevails, has a higher percentage of silicates. The ratio between carbonated and silicate clasts determines the petrophysical quality of the rock; the sandstone studied here is a member of the $Q_{2} B T$ compositional family (3-4).

Uncastillo and Ayerbe sandstone is found in the Lower Miocene (Aquitanian - Burdigalian) Uncastillo formation (5), which extends across the northern part of the Ebro depression to the foothills. It consists in alternating layers of clay and sandstone, occasionally appearing as isolated braided deposits formed by fluvial flows in alluvial fans originating in the foothills.

The Uncastillo sandstone studied is extracted at the Martínez quarry from lenticular, subhorizontal beds up to 
lenticulares de hasta 3 metros de potencia y con continuidades laterales de 50 a 90 metros. Existe gran variabilidad en cuanto al tamaño de grano, siendo la de tamaño medio la más trabajada. Las principales discontinuidades existentes son diaclasas con 1,5-3 m de espaciado y la presencia de niveles arcillosos intercalados de origen fluvial. Los bloques extraídos son de 2,5 x 1,7 × 1,8 metros.

La arenisca de Ayerbe estudiada se explota en la cantera San Julián a partir de niveles tabulares y lenticulares subhorizontales de continuidad lateral variable que presentan una potencia comprendida entre los $35 \mathrm{~cm}$ y 5,5 metros. Estos paquetes de areniscas se encuentran intercalados con potentes paquetes de arcillas y limos. El diaclasado presenta un espaciado 1-2 m.

La arenisca de Alcañiz pertenece a la Fm Caspe (edad Aquitaniense). Se trata de una formación detrítica con características litológicas y morfológicas variables (6). La sedimentación terciaria es principalmente detrítica (lutitas y areniscas) alternada con episodios carbonáticos y evaporíticos con un relleno subhorizontal que presenta una suave inclinación hacia el N y NW.

La arenisca de Alcañiz estudiada se explota en la cantera El Cielo en bancos subhorizontales y poco deformados de hasta $6 \mathrm{~m}$ de potencia, separados por interestratos arcillosos-limosos. El diaclasado presenta un espaciado de orden métrico (4-5 m).

\section{PARTE EXPERIMENTAL}

En las tres canteras se efectuó un muestreo representativo en los frentes activos de las explotaciones para la ejecución de todos los ensayos recogidos en este trabajo. Con los datos obtenidos, se realizó una evaluación tecnológica del material con el objetivo de valorar su calidad como materiales de usos constructivos, mediante la realización de una caracterización petrográfica, física y mecánica mediante diferentes ensayos normalizados.

La caracterización petrográfica se realizó mediante el estudio de varias láminas delgadas (con tinción combinada de alizarina roja S y ferrocianuro potásico), pulidas y superficies de fractura de cada variedad pétrea al microscopio óptico de luz transmitida modelo Carl Zeiss Jena-Pol y al MEB modelo Zeiss DSM 942. Asimismo, mediante análisis digital de imágenes aplicado tanto al microscopio petrográfico, como al microscopio electrónico de barrido, se ha realizado la caracterización y cuantificación del sistema poroso de cada material. La fracción arcillosa presente en las areniscas se estudió mediante difracción de rayos $X$ en un difractómetro Philips 1710. three metres thick and from 50 to 90 metres long. Grain size varies widely, although the intermediate size is the one most quarried. The main discontinuities are joints spaced at $1.5-3 \mathrm{~m}$ and interbedded layers of fluvial clay. The blocks quarried measure $2.5 \times 1.7 \times 1.8$ metres.

The Ayerbe sandstone is taken from San Julián quarry from subhorizontal tabular and lenticular layers of varying length and thickness (35 cm to $5.5 \mathrm{~m}$ ). These sandstone packages lie in between packages of clay and siltstone, with joints spaced at 1-2 m.

The Alcañiz sandstone pertains to the Caspe formation (Aquitanian geologic time). Both the lithological and morphological characteristics of this detrital formation vary (6). The Tertiary sedimentation is primarily detrital (lutite and sandstone) with alternating carbonate and evaporite formations and a sub-horizontal fill sloping slightly north-northwestward.

This stone is extracted at El Cielo quarry from sub-horizontal layers up to $6 \mathrm{~m}$ thick, separated by interbedded clay-silt strata. Joint spacing (4-5 m) follows a metric pattern.

\section{EXPERIMENTAL}

Representative samples were taken from the quarry faces in the three sites for all the tests performed in this study. The material was evaluated for use in construction on the grounds of its petrographic, physical and mechanical characteristics found by conducting standardized tests.

Petrographic characterization consisted in optical and BSEM microscope studies of several polished thin layers (dyed with a combination of alizarine red $S$ and potassium ferrocyanide) and the fracture surfaces of each variety of stone, conducted respectively with a Carl Zeiss Jena-Pol transmitted light optical microscope and a Zeiss DSM 942 BSEM. Moreover, the pore networks for all the materials were characterized and quantified via digital image analysis applied to both the petrographic and back-scattering electron microscope findings. The clay fraction present in the sandstone was studied via $X$-ray diffraction on a Philips 1710 diffractogram. 
La medición del color se realizó utilizando la escala CIELAB (7) mediante un espectrofotómetro modular SFLO-01 y mediante las cartas Munsell (8) de color. Las coordenadas de color se determinaron mediante la utilización de luz difusa con el iluminante D65 (que corresponde a la luz natural con radiación ultravioleta), de temperatura de color $6.500 \mathrm{~K}$. Para cada muestra se ha determinado el valor de las coordenadas promedio $L^{*}, a^{*}$ y $b^{*}$ ( $L^{*}$ representa la luminosidad del color y varía de 0 - negro 100 blanco, a* varía entre $+a^{*}$ rojo y -a* verde, y b* varía entre $+b^{*}$ amarillo y $-b^{*}$ azul) en 4 puntos diferentes. La geometría de medida ha sido de $8^{\circ}$ difusa y observador CIE $10^{\circ}$. Las mediciones se han realizado sobre dos acabados superficiales diferentes: corte sierra y abujardado.

La caracterización física y mecánica se ha realizado siguiendo las recomendaciones de las normas UNE (914), ASTM (15), RILEM (16) y NORMAL (17). Además, se ha realizado una valoración estadística de los resultados de los ensayos con el objetivo de valorar las posibles heterogeneidades y anisotropías del material. Todos los ensayos realizados de cada tipo litológico se han efectuado sobre tandas de 6 probetas extraídas de un mismo bloque.

Los ensayos físicos realizados han sido: absorción de agua, desorción de agua, absorción de agua por capilaridad, expansión hídrica, porosidad abierta y total y densidad aparente y real, realizándose todos ellos sobre las mismas probetas de dimensiones $7 \times 7 \times 7 \mathrm{~cm}$.

Los ensayos mecánicos realizados han sido: resistencia a compresión, resistencia a flexión antes y después del ensayo de heladicidad, velocidad de ultrasonidos, resistencia al desgaste por abrasión y resistencia al deslizamiento sin pulimento.

Los ensayos mecánicos de resistencia a compresión simple y de flexión se han realizado mediante las prensas Ibertest de $150 \mathrm{Tn}$ con un equipo electrónico acoplado Sce M-4214 con una velocidad de carga de 0,3 MPa/s y con una prensa controls, Multiensayo, célula de carga $\mathrm{PCI}$, respectivamente.

La velocidad de ultrasonidos se ha medido con el equipo ultrasonic tester C-370, calculándose la anisotropía del material mediante los valores de velocidad en la dirección paralela (V1) y perpendicular (V2) a la estratificación mediante la fórmula: $\left[\mathrm{vp}_{1}-\mathrm{vp}_{2} / \mathrm{vp}_{2}\right]^{* 100}$ (18). La importancia de este parámetro se debe a la relación existente entre la velocidad de propagación de ultrasonidos y las características petrológicas que influyen en la resistencia mecánica del material.

La evaluación de la durabilidad se ha realizado con el objetivo de valorar la resistencia a la alteración de cada
Colour was measured to the CIELAB (7) scale with a modular SFLO-01 spectrophotometer, as well as with Munsell (8) colour charts. Colour coordinates were determined under a D65 illuminant dispersed light source (equivalent to natural daylight with ultraviolet radiation) at a colour temperature of $6500 \mathrm{~K}$. The mean of four measurements of the $L^{*}, a^{*}$ and $b^{*}$ coordinates at four different points was found for each sample ( $L^{*}$ being colour luminosity, which varies from 0 or black to 100 or white; $a^{*}$ varies from $+a^{*}$ red to $-a^{*}$ green, and $b^{*}$ from $+b^{*}$ yellow to $-b^{*}$ blue). Measuring geometry was $8^{\circ}$ of dispersion with the CIE observer at an angle of $10^{\circ}$. The measurements were taken on both sawn and bush-hammered surface finishes.

Physical and mechanical characterization was performed to the recommendations contained in (Spanish) UNE (9-14), ASTM (15), RILEM (16) and NORMAL (17) standards. In addition, statistical analyses were run on the test results to assess possible non-uniformities or anisotropy in the material. All the tests performed for each stone type were conducted on series of six specimens taken from the same specimen.

The physical tests included: water absorption and desorption, capillary water uptake, water swelling, open and total porosity and real and bulk density, all run on the same $7 \times 7 \times 7 \mathrm{~cm}$ specimens.

The mechanical tests included: compressive strength, flexural strength before and after the freeze-thaw test, ultrasound velocity, abrasion resistance and unpolished slip resistance.

The compressive and flexural strength tests were conducted on a 150-t Ibertest testing machine fitted with an Sce M-4214 electronic 0.3-MPa/s load cell, and a Multiensayo testing machine fitted with a PCI load cell, respectively.

Ultrasound velocity was measured with a C-730 ultrasonic tester; material anisotropy was computed from the velocity values parallel (V1) and perpendicular (V2) to stratification with the formula: $\left[v p_{1-} v p_{2} / v p_{2}\right]^{*} 100$ (18). The importance of this parameter lies in the relationship between ultrasound velocity and the petrological characteristics that affect the mechanical strength of the material.

Durability was evaluated to assess the resistance to alteration in each sandstone. The tests conducted included 
una de las tres areniscas. Los ensayos realizados han sido el ensayo de heladicidad mediante la cámara frigorífica DYCOMETAL, modelo CHD -525 según la norma (19)* y el ensayo de cristalización de sales según la norma (20). El ensayo de heladicidad también se ha realizado sobre probetas que posteriormente han sido sometidas al ensayo de resistencia a flexión con el objetivo de evaluar la influencia de los ciclos de hielo-deshielo en la resistencia mecánica de estos materiales.

\section{RESULTADOS}

\subsection{Características petrográficas}

Petrográficamente, estas rocas se clasifican como litoarenitas de grano medio (21) (Tablas 1-2) y color naranja grisáceo. El tamaño de grano, forma y selección de las areniscas estudiadas son muy homogéneos, los clastos son subangulosos-subredondeados con tamaños medios de 0,25 a 0,35 mm y máximos de 0,7 a 0,9 mm, esfericidad baja y una selección buena 1,2-1,4 (22).

El esqueleto granosostenido de estas areniscas está constituido por fragmentos de rocas carbonatadas tanto calcíticos como dolomíticos (policristalinos, monocristalinos y micríticos), fragmentos de rocas metamórficas y volcánicas, cuarzos (monocristalino y policristalino) y feldespatos freeze-thaw in a DYCOMETAL CHD-525 cold chamber to UNE 67-028-97-EX* (19) specifications, and salt crystaIlization to NORMAL 25-PEM (20) specifications. The freeze-thaw test was also conducted on specimens that were subsequently tested for flexural strength to evaluate the effect of freeze-thaw cycles on material mechanical strength.

\section{RESULTS}

\subsection{Petrographic characteristics}

Petrographically, these rocks can be classified as greyish-orange, medium-grained litharenitic sandstones (21) (Tables 1-2). The sandstones studied exhibited very uniform grain sizes, forms and textural sorting; subangular-subrounded clasts with a mean size of 0.25 to 0.35 $\mathrm{mm}$ and a maximum size of 0.7 to $0.9 \mathrm{~mm}$; low sphericity; and a narrow range of sorting values 1.2-1.4 (22).

The grain-supported skeleton of these stones consisted in fragments of (micrite, mono- and polycrystalline) calcite and dolomite carbonated rock fragments of metamorphic and volcanic rock, (mono- and polycrystalline) quartz and feldspars (Figure 1). Traces of zircon,

Tabla 1 / Table 1

Composición mineralógica (\%). Contaje de 500 puntos por lámina Mineralogical composition (\%). We have counted 500 points by thin section

\begin{tabular}{|c|c|c|c|}
\hline & Uncastillo & Ayerbe & Alcañiz \\
\hline Calcita (\%) / Calcite (\%) & 59.27 & 38.04 & 49.53 \\
\hline Dolomita (\%) / Dolomite (\%) & 0.82 & 1.70 & 10.05 \\
\hline Cuarzo (\%) / Quartz (\%) & 13.70 & 30.59 & 31.18 \\
\hline Feldespato (\%) / Feldespart (\%) & 2.16 & 3.29 & 2.71 \\
\hline Micas (\%) / Micas (\%) & 0.95 & 0.54 & 0.30 \\
\hline Lit. no carbonatado (\%) / Lit. no carbonated (\%) & 21.59 & 22.20 & 2.06 \\
\hline Matriz y óxidos de hierro (\%) / Matrix and iron oxides (\%) & 1.50 & 3.65 & 4.22 \\
\hline Relación carbonato/silicato / Ratio carbonate/silicate & 1.56 & 0.70 & 1.64 \\
\hline Relación calcita/cuarzo / Ratio calcite/quartz & 4.33 & 1.24 & 1.60 \\
\hline
\end{tabular}

\footnotetext{
* Justificación del uso de la Norma UNE 67028 EX. Ensayos previos realizados sobre estos materiales con la norma de Piedra Natural demostraron que la pérdida en peso en estas areniscas era inferior al $0,03 \%$, por ello se decidió usar la cámara climática automática homologada según la norma UNE 67028 EX que nos permitió realizar los 25 ciclos del ensayo sin manipulación de las probetas, manteniendo unos rangos de temperatura similares a los indicados por la norma UNE para piedra natural, con el objetivo de evaluar la variación en la resistencia mecánica del material tras heladicidad (método más relevante para evaluar los efectos del hielo sobre el material).
}

\footnotetext{
* Justification of the use of Spanish UNE standard 67028 EX. Prior tests conducted on these materials showed that the weight loss in these sandstones was under $0.03 \%$. Consequently, an automatic cold chamber meeting UNE 67028 EX requirements was used, with which 25 test cycles could be run without handling the specimens while maintaining the temperature within ranges similar to those specified by the UNE standard for natural stone. Subsequently, the variation in mechanical strength was found in specimens subjected to the freeze-thaw procedure (most effective method for assessing the effects of freezing on the material).
} 
(Figura 1). Como accesorios se encuentran zircón, esfena, turmalina, piroxeno, óxidos de hierro y moscovita. sphene, turmaline, pyroxene, iron oxide and muscovite were also found.

Tabla 2 / Table 2

Minerales de la arcilla identificados por difracción de rayos $X$

$X$ ray diffraction of the clay minerals

\begin{tabular}{|l|c|c|c|}
\hline & Uncastillo & Ayerbe & Alcañiz \\
\hline Esmectita (\%) / Smectite (\%) & 5 & 5 & 7 \\
\hline Illita (\%) / Illite (\%) & 69 & 71 & 45 \\
\hline Clorita (\%) / Chlorite (\%) & 14 & 16 & 12 \\
\hline Caolinita (\%) / Kaolinite (\%) & 12 & 8 & 36 \\
\hline
\end{tabular}

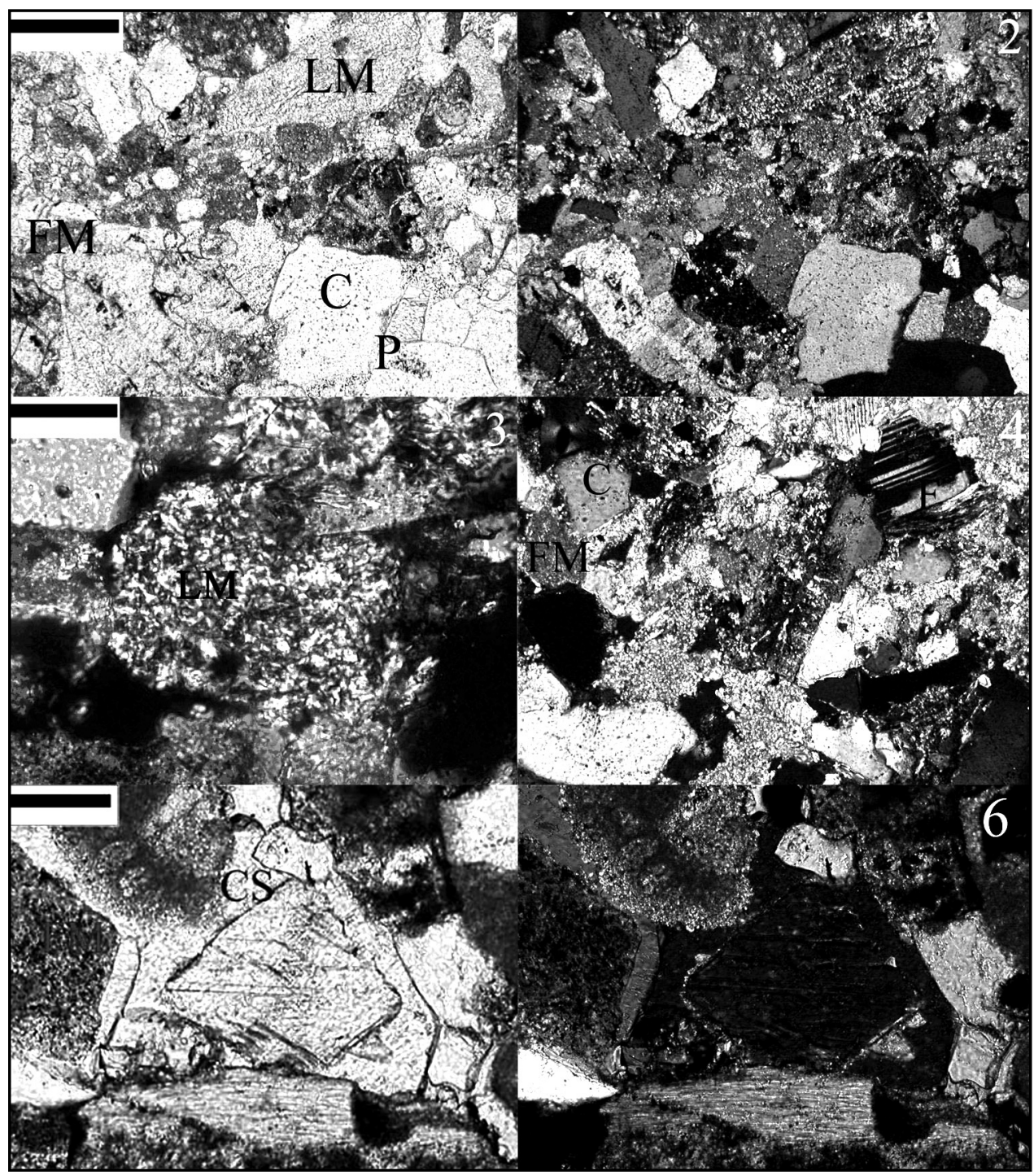

Figura 1. Imágenes de las areniscas, preparadas en forma de láminas delgadas, al microscopio petrográfico. (1-3-5) Nícoles paralelos; (2-4-6) Nícoles cruzados. [Líticos metamórficos (LM), cuarzo

(C), líticos carbonatados (FM), plagioclasa (F), cemento sintaxial de calcita (CS), Poros (P).]

1-2 Uncastillo (escala $250 \mu \mathrm{m}$ ), 3-4 Ayerbe (3 escala 48,5 $\mu \mathrm{m}$ - 4 escala $250 \mu \mathrm{m}$ ), 5-6 Alcañiz (escala $125 \mu \mathrm{m}$ ).

Figure 1. Thin section of the sandstone components observed under the petrographic microscope. (1-3-5) Parallel-polars, (2-4-6) Crossed-polars. [Metamorphic fragment (LM), quart (C), carbonated fragments $(F M)$, feldspar (F), calcite cement (CS), pores $(P)$.]

1-2 Uncastillo (bar length $250 \mu \mathrm{m}$ ), 3-4 Ayerbe (3 bar length 48,5 $\mu \mathrm{m}$ - 4 bar length $250 \mu \mathrm{m}$ ), 5-6 Alcañiz (bar length $125 \mu \mathrm{m}$ ). 
El cemento es carbonático esparítico y sintaxial en un 90$95 \%$ y de cuarzo sintaxial en un $5-10 \%$. El cemento carbonático esparítico es, en ocasiones, de calcita férrica $(1,5 \%-2,5 \%$ de $\mathrm{Fe})$.

Aunque macroscópicamente estas rocas son bastante similares, el estudio al microscopio revela la existencia de importantes diferencias entre ellas. Petrográficamente, la arenisca de Uncastillo se caracteriza por presentar una elevada relación calcita-cuarzo $(4,3)$ y un alto porcentaje de líticos metamórficos, lutíticos y volcánicos $(21,6 \%)$, la arenisca de Ayerbe se caracteriza por presentar una baja relación calcita-cuarzo $(1,24 \%)$ y un porcentaje alto de líticos metamórficos, lutíticos y volcánicos (22\%), mientras que la arenisca de Alcañiz se caracteriza por presentar un elevado contenido en dolomita (10\%), turmalina (2-3\%) y por la escasez de líticos metamórficos, lutíticos y volcánicos (2\%).

\subsection{Características petrofísicas}

\subsubsection{Ensayos físicos}

Los resultados de los ensayos físicos se resumen en las Tablas 3-4.

El color que presentan las areniscas de la Fm Uncastillo (Ayerbe y Uncastillo) es similar entre sí y con un valor de luminosidad ligeramente superior al de la arenisca de Alcañiz (Tabla 3). Las tres variedades presentan una variación mínima de las coordenadas cromáticas en función de sus acabados.

El comportamiento hídrico del material junto con las condiciones ambientales tras su puesta en obra van a ser los factores que van a controlar principalmente la degradación de los materiales pétreos (23). Estas areniscas presentan valores semejantes entre sí de densidad real y densidad aparente (Tabla 4), no presentan expansión hídrica y poseen una porosidad media-alta, Alcañiz, 13,06\%; Uncastillo, $14,16 \%$; y Ayerbe, $16,86 \%$. El tamaño promedio de diámetro de poro de estas areniscas calculado por análisis

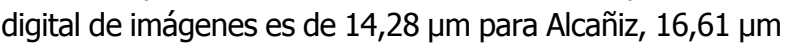
para Uncastillo y $17,89 \mu \mathrm{m}$ para Ayerbe.
The cement was found to be $90-95 \%$ sparite and microsparite carbonate and 5-10\% silica. In some cases the sparite carbonate cement was in the form of ferric calcite $(1.5-2.5 \% \mathrm{Fe})$.

Although macroscopically speaking these rocks are fairly similar, the microscopic study revealed important differences among them. The petrographic results showed Uncastillo sandstone to be characterized by a high calcite-quartz ratio (4.3) and a high percentage of metamorphic, lutite and volcanic stones (21.6\%). Ayerbe sandstone exhibited a low calcite-quartz ratio (1.24\%) and a high percentage of metamorphic, lutite and volcanic stones (22\%). Lastly, Alcañiz sandstone was found to have a high dolomite (10\%) and turmaline (2-3\%) content and scant metamorphic, lutite or volcanic stone (2\%).

\subsection{Petrophysical characteristics}

\subsubsection{Physical trials}

The results of the physical trials are summarized in Tables 3-4.

The colour of the Uncastillo (Ayerbe and Uncastillo) formation sandstone was observed to be similar throughout and have slightly higher luminosity than the Alcañiz variety (Table 3). None of the stones showed any significant variation in the chromatic coordinates with different finishes.

Stone decay depends primarily on the permeability of the material and the environmental conditions prevailing once it is laid (23). These sandstones showed similar real and bulk density values (Table 4), no water swelling and medium-high porosity: Alcañiz 13.06\%, Uncastillo $14.16 \%$ and Ayerbe $16.86 \%$. The mean pore diameter in these stones, computed by digital image analysis, was 14.27 $\mu \mathrm{m}$ for Alcañiz, $16.61 \mu \mathrm{m}$ for Uncastillo and $17.89 \mu \mathrm{m}$ for Ayerbe.

Tabla 3 / Table 3

Parámetros cromáticos

Chromatic parameters

\begin{tabular}{|c|c|c|c|c|}
\hline \multicolumn{5}{|c|}{$10 \%$ D 65} \\
\hline & $\mathbf{L *}^{*}$ & a* & b* & Munsell \\
\hline Uncastillo - Corte sierra / Uncastillo - sawn & 70.8 & 2.2 & 15.5 & $10 Y R 7 / 4$ \\
\hline Uncastillo - Abujardado / Uncastillo - hammered & 68.2 & 2.3 & 16.3 & $10 \mathrm{YR} 7 / 4$ \\
\hline Alcañiz - Corte sierra / Alcañiz - sawn & 63.3 & 6.1 & 22.3 & $10 \mathrm{YR} 8 / 4$ \\
\hline Alcañiz - Abujardado / Alcañiz - hammered & 64.9 & 6.4 & 22.6 & 10YR8/4 \\
\hline
\end{tabular}


Tabla 4 / Table 4

Propiedades hídricas y físicas de las tres variedades de areniscas Hydric and physical properties of the three types of sandstone

\begin{tabular}{|c|c|c|c|}
\hline & Uncastillo & Ayerbe & Alcañiz \\
\hline Absorción (\%) / Absorption (\%) & 4.61 & 5.73 & 3.89 \\
\hline Densidad aparente $\left(\mathrm{gr} / \mathrm{cm}^{3}\right) /$ Apparent density $\left(\mathrm{gr} / \mathrm{cm}^{3}\right)$ & 2.27 & 2.20 & 2.28 \\
\hline Densidad real $\left(\mathrm{gr} / \mathrm{cm}^{3}\right) /$ Real density $\left(\mathrm{gr} / \mathrm{cm}^{3}\right)$ & 2.63 & 2.64 & 2.62 \\
\hline Porosidad abierta (\%) / Open porosity (\%) & 10.43 & 12.63 & 8.86 \\
\hline Porosidad total (\%) / Total porosity (\%) & 14.16 & 16.86 & 13.06 \\
\hline Porosidad inaccesible (\%) / Inaccesible porosity (\%) & 3.73 & 4.23 & 4.20 \\
\hline Coef. saturación 1 h (\%) / Saturation coef. 1 h (\%) & 62.60 & 71.22 & 74.87 \\
\hline Coef. saturación 8 h (\%) / Saturation coef. 8 h (\%) & 67.54 & 75.00 & 76.91 \\
\hline Coef. saturación 24 h (\%) / Saturation coef. 24 h (\%) & 73.07 & 79.01 & 80.31 \\
\hline Coef. absorción capilar $\left(\mathrm{g} / \mathrm{cm}^{2} . \mathrm{s}^{0,5}\right) /$ Coef. of capillary absorption $\left(\mathrm{g} / \mathrm{cm}^{2} . \mathrm{s}^{0,5}\right)$ & 0.0013 & 0.0088 & 0.0073 \\
\hline Absorción capilar $\left(\mathrm{g} / \mathrm{cm}^{2}\right)$ / Capillary absorption & 0.65 & 0.86 & 0.61 \\
\hline Retención de agua (\%) / Water retention (\%) & 19.30 & 25.78 & 4.51 \\
\hline Dilatación hídrica (\%) / Hygric swelling (\%) & 0.0003 & 0.0023 & 0.0112 \\
\hline
\end{tabular}

La absorción de agua en estas areniscas está comprendida entre 5,73\% de Ayerbe y 3,89\% de Alcañiz. En la Figura 2 se muestra la absorción libre de agua respecto a la raíz cuadrada del tiempo para las tres areniscas. Las areniscas de Uncastillo y Ayerbe presentan un comportamiento similar entre sí y diferente al de la arenisca de Alcañiz. Esta arenisca presenta una absorción inicial más rápida (consecuencia de la mejor conexión de sus macroporos), absorbiendo el $60 \%$ en 1,5 minutos, mientras que Uncastillo y Ayerbe tardan 7 y 8 minutos, respectivamente. Después de alcanzar el $70 \%$ de saturación, Alcañiz pasa a tener una absorción más lenta que Uncastillo y Ayerbe.

La Figura 3 muestra la cinética del ensayo de desorción. La desorción inicial en las tres areniscas es rápida hasta llegar al punto crítico (punto de inflexión) a partir del cual las probetas se secan de una forma mucho más lenta. La desorción en la arenisca de Alcañiz es la más

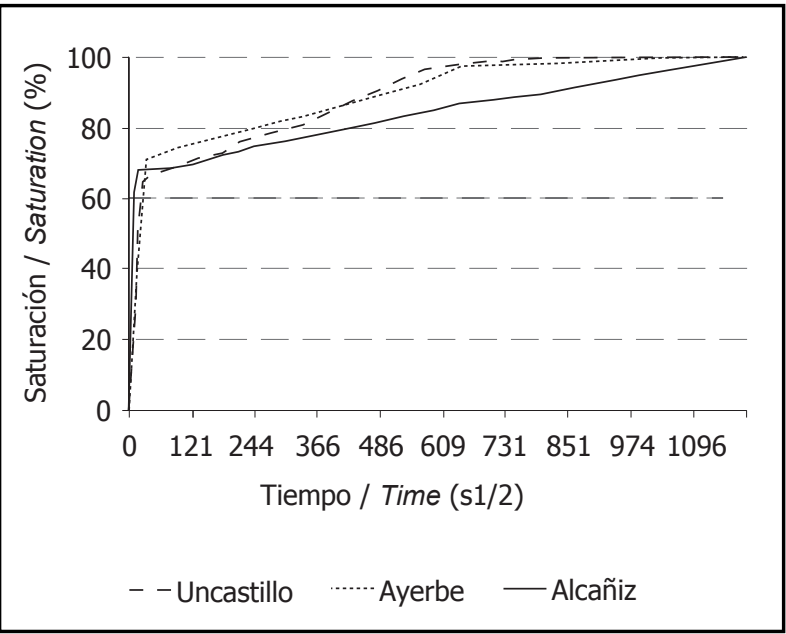

Figura 2. Absorción libre de agua. Figure 2. Free water absorption.
Water absorption ranged from $5.73 \%$ in Ayerbe to $3.89 \%$ in Alcañiz. Water absorption for the three sandstones is plotted against the square root of time in Figure 2. The Uncastillo and Ayerbe varieties exhibited similar behaviour, which differed from the behaviour observed in Alcañiz sandstone. Absorption in the third was initially faster (due to better macropore interconnections), absorbing $60 \%$ in 1.5 minutes, compared to the 7 and 8 minutes for Uncastillo and Ayerbe, respectively. After reaching 70\%, however, Alcañiz exhibited slower absorption than Uncastillo and Ayerbe.

Figure 3 shows the desorption test kinetics. Desorption, initially rapid in the three stones, slowed after reaching the critical point (inflection point). Desorption was most effective in Alcañiz sandstone, which had lower water retention at atmospheric pressure (4.5\%) than both

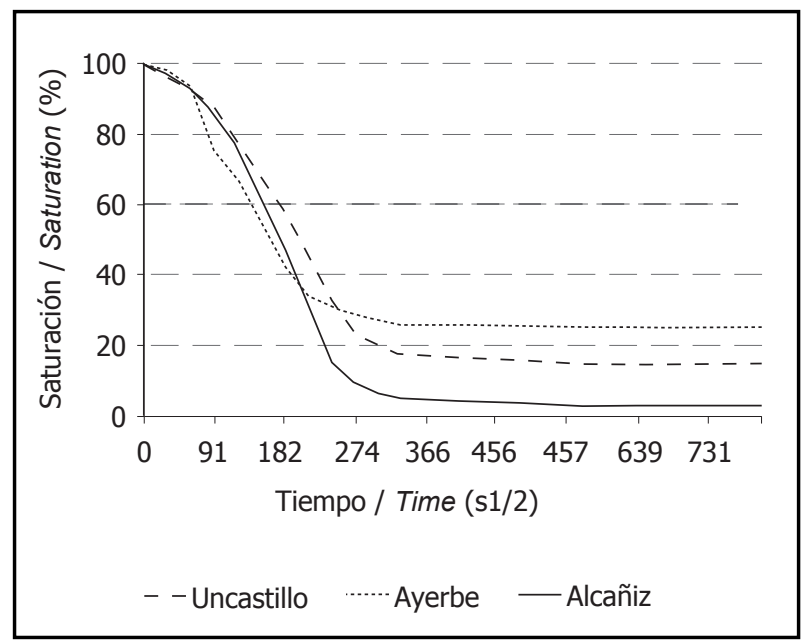

Figura 3. Desorción de agua.

Figure 3. Kinetics desorption graphs. 
eficaz de las tres, presentando la menor retención de agua tras secado a presión atmosférica con un 4,5\% frente al $19,3 \%$ de Uncastillo y el $25,78 \%$ de Ayerbe. Un mayor tiempo de residencia del agua en el interior del material implicará una mayor alterabilidad potencial del mismo.

El coeficiente de absorción capilar es muy similar para las areniscas de Ayerbe y de Alcañiz con valores de 0,088 $\mathrm{g} / \mathrm{cm}^{2} \cdot \mathrm{s}^{0,5}$ y $0,0072 \mathrm{~g} / \mathrm{cm}^{2} \cdot \mathrm{s}^{0,5}$, respectivamente, y ligeramente inferior para Uncastillo $0,0013 \mathrm{~g} / \mathrm{cm}^{2} \cdot \mathrm{s}^{0,5}$. En la Figura 4 se muestra la cantidad de agua que han absorbido estas areniscas por capilaridad, siendo similar para las areniscas de Alcañiz y Uncastillo y superior para la arenisca de Ayerbe.

\subsubsection{Ensayos mecánicos}

Los resultados de los ensayos mecánicos se muestran en la Tabla 5. Los ensayos mecánicos se han realizado sobre probetas con diferentes orientaciones, posteriormente se ha realizado un estudio estadístico de análisis de la varianza (ANOVA) para valorar el comportamiento del material. Estos resultados indican que las tres areniscas presentan un comportamiento diferente en función de las propiedades medidas. Las areniscas de Uncastillo y Ayerbe son anisótropas respecto al ensayo de resistencia al desgaste por abrasión, mientras que la arenisca de Alcañiz es anisótropa respecto al ensayo de flexión.

Los resultados del ensayo de compresión simple para las areniscas de Uncastillo y Alcañiz son un 35\% superior al de la arenisca de Ayerbe. El ensayo de flexión se ha realizado con tres orientaciones diferentes, mostrando unos valores superiores en las areniscas de Ayerbe y Alcañiz respecto a la arenisca de Uncastillo. Los ensayos de flexión realizados tras heladicidad han supuesto un aumento en la resistencia mecánica de estos materiales respecto al material ensayado antes de heladicidad.

Los resultados de los ensayos de resistencia tanto al desgaste por abrasión como al deslizamiento sin pulido para la arenisca de Alcañiz son muy favorables, presentando unos valores óptimos para su uso en pavimentación.

La velocidad de propagación de ultrasonidos oscila entre 3008,72 m/s de Ayerbe y 3788,2 m/s de UncastiIlo. La arenisca de Alcañiz presenta el valor más bajo de anisotropía (2,88\%), mientras que en Uncastillo es de $7,80 \%$ y en Ayerbe de 6,38\% (Tabla 5). Este dato junto con los valores obtenidos en los coeficientes de variación para los ensayos físicos y mecánicos indican una mayor homogeneidad estructural en la arenisca de Alcañiz.
Uncastillo (19.3\%) and Ayerbe (25.78\%). The longer water remains inside the material the greater is its potential alterability.

The water absorption coefficient was similar for the Ayerbe and Alcañiz sandstones, with values of 0.088 $\mathrm{g} / \mathrm{cm}^{2} . \mathrm{s}^{0.5}$ and $0.0072 \mathrm{~g} / \mathrm{cm}^{2} . \mathrm{s}^{0.5}$, respectively, and slightly lower for Uncastillo, at $0.0013 \mathrm{~g} / \mathrm{cm}^{2} . \mathrm{s}^{0.5}$ Figure 4 shows the amount of capillary water absorbed by these sandstones, which was similar for Alcañiz and Uncastillo and higher for Ayerbe.

\subsubsection{Mechanical tests}

The results of the mechanical tests are given in Table 5. These tests were conducted on specimens using different load orientations and an ANOVA was subsequently run on the findings to assess the behaviour of the material. The results showed that the three sandstones exhibited different behaviour depending on the property tested. The Uncastillo and Ayerbe materials were anisotropic for abrasion resistance while the Alcañiz stone was anisotropic for bending strength.

The Uncastillo and Alcañiz stones had 35\% higher compressive strength than the Ayerbe material. The flexural strength test, conducted with three different loading directions, showed the Ayerbe and Alcañiz sandstones to be stronger than the Uncastillo variety. According to the bending strength tests conducted after freeze-thaw cycles, strength increased in all three materials after the cycles.

According to the very favourable results of both the abrasion and unpolished slip resistance tests for the Alcañiz stone, this material is apt for use in paving.

Ultrasound velocity ranged from $3008.72 \mathrm{~m} / \mathrm{s}$ in Ayerbe to $3788.2 \mathrm{~m} / \mathrm{s}$ in Uncastillo. Anisotropy was lowest in the Alcañiz stone, at $2.88 \%$, compared to the $7.80 \%$ in Uncastillo and $6.38 \%$ in Ayerbe sandstone (Table 5). This, along with the values obtained for the physical and mechanical tests, is indicative of greater structural uniformity in the Alcañiz stone. 
Tabla 5 / Table 5

Propiedades mecánicas de las tres variedades de areniscas

Mechanical properties of the three types of sandstone varieties

\begin{tabular}{|l|c|c|c|}
\hline Ensayos mecánicos / Mechanical tests & Uncastillo & Ayerbe & Alcañiz \\
\hline Resistencia compresión (MPa) / Compressive strength (MPa) & 39.23 & 25.72 & 38.36 \\
\hline Resistencia flexión a (MPa) / Flexural strength a (MPa) & 3.24 & 4.90 & 4.61 \\
\hline Resistencia flexión b (MPa) / Flexural strength b (MPa) & 3.10 & 4.21 & 4.30 \\
\hline Resistencia flexión c (MPa) / Flexural strength c (MPa) & 3.01 & 4.95 & 6.35 \\
\hline $\begin{array}{l}\text { Resistencia flexión tras heladicidad a (MPa) } \\
\text { Flexural strength after freeze-thaw test a (MPa) }\end{array}$ & 3.88 & 6.08 & 5.32 \\
\hline $\begin{array}{l}\text { Resistencia flexión tras heladicidad b (MPa) } \\
\text { Flexural strength after freeze-thaw test b (MPa) }\end{array}$ & 3.41 & 3.60 & 4.65 \\
\hline $\begin{array}{l}\text { Resistencia flexión tras heladicidad c (MPa) } \\
\text { Flexural strength after freeze-thaw test c (MPa) }\end{array}$ & 4.97 & 5.24 & 6.61 \\
\hline Resistencia desgaste por abrasión paralela (mm) / Abrasion resistance (parallel) (mm) & 31.50 & 42.00 & 19.00 \\
\hline Resistencia desgaste por abrasión perpendicular (mm) / Abrasion resistance (perpendicular) (mm) & 22.50 & 34.20 & 20.60 \\
\hline Resistencia al deslizamiento sin pulido / Sliding resistance (USRV) & 71 & 70 & 71 \\
\hline V. Propag. Ultrasonidos (m/s) / Ultrasound speed (m/s) & 3788.20 & 3008.72 & 3571.21 \\
\hline
\end{tabular}

\subsection{Durabilidad}

La durabilidad de estos materiales se ha estimado mediante los ensayos de envejecimiento acelerado de heladicidad y de cristalización de sales con sulfato de sodio. Las tres areniscas han presentado un buen comportamiento frente al ensayo de heladicidad considerándose material no heladizo. En cambio, en el ensayo de cristalización de sales han presentando diferentes comportamientos (Figura 5). La arenisca de Alcañiz es la que presenta un mejor comportamiento con una pérdida en peso del $7,7 \%$ frente al $39,87 \%$ de Uncastillo y al $43,85 \%$ de Ayerbe.

\section{CONCLUSIONES}

Las tres areniscas miocenas del valle del Ebro investigadas se clasifican, según Pettijohn, como litoarenitas de grano medio con textura granosostenida. Las areniscas de Uncastillo y Ayerbe pertenecen a la Fm Uncastillo, mientras que la arenisca de Alcañiz pertenece a la Fm Caspe. Los materiales estudiados se localizan en el sector central del valle del Ebro, donde las facies detríticas del Terciario mediosuperior están interpretadas como sedimentos fluviales de sistemas aluviales con regímenes variados. Estas areniscas presentan una cierta variabilidad en sus características petrofísicas en puntos diferentes de la misma cantera, por lo que es de gran importancia realizar una caracterización y selección del material. Esta variabilidad es especialmente reducida en la arenisca de Alcañiz, presentando la mayor homogeneidad en los resultados para todos los ensayos.

Estas rocas se pueden definir desde el punto de vista de su comportamiento físico y mecánico como homogéneas e isótropas-anisótropas en función de la propiedad medida. Presentan un valor industrial notable por sus excelentes propiedades como materiales para

\subsection{Durability}

Durability was estimated in these materials by accelerated ageing tests consisting in freeze-thaw cycles and sodium sulphide salt crystallization. The three stones performed well in the freeze-thaw test, and can be regarded to be unaffected by low temperatures. They showed differential behaviour in the salt crystallization test, however (Figure 5). With a weight loss of $7.7 \%$, the Alcañiz stone performed best: the figures for Uncastillo and Ayerbe were $39.87 \%$ and $43.85 \%$, respectively.

\section{CONCLUSIONS}

The three Miocene sandstones from the Ebro Valley studied are, according to the Pettijohn classification, medium-grained lithoarenites with a grain-supported fabric. The Uncastillo and Ayerbe sandstones pertain to the Uncastillo, and the Alcañiz stone to the Caspe formation. The materials studied are located in the central sector of the Ebro Valley, where the detrital facies of the Mid-Upper Tertiary is interpreted to consist in fluvial deposits in alluvial fans characterized by a number of different flow regimes. The petrophysical characteristics of these sandstones vary within each quarry, making material characterization and selection particularly important. The Alcañiz stone exhibited much lower variability and greater uniformity in all the test results.

In terms of physical and mechanical behaviour, these rocks can be regarded to be uniform, and isotropic or anisotropic depending on the property measured. Particularly apt for use in construction, they have substantial industrial value. They can be classified as moderately hard on the 


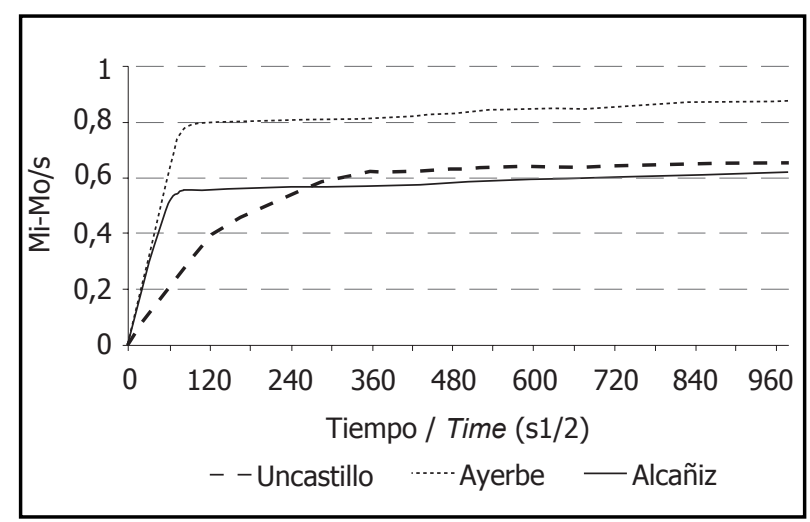

Figura 4. Absorción capilar de agua. Figure 4. Water capillarity absorption.

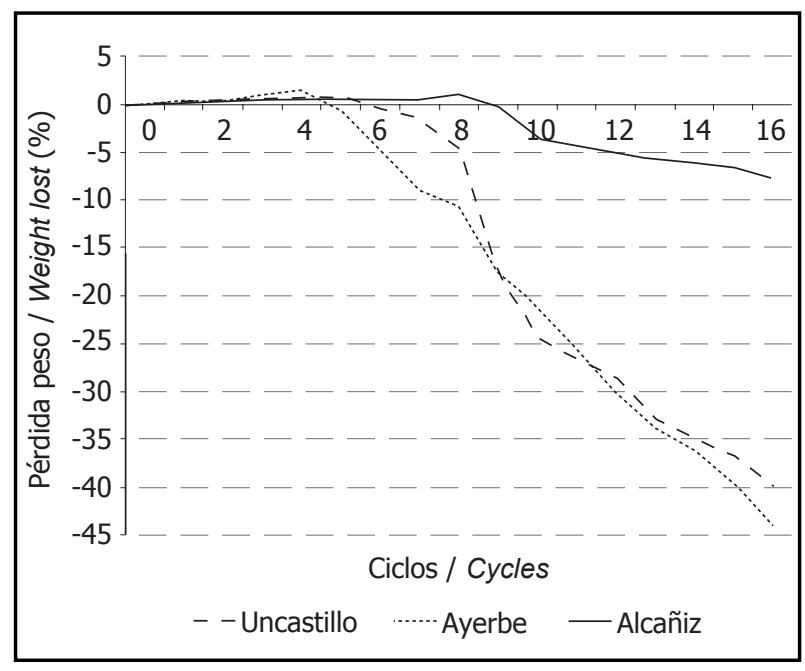

Figura 5. Cristalización de sales. Pérdida de peso expresada como porcentaje del peso inicial de la probeta seca.

Figure 5. Salt cristallization test. Loss of weight expressed as a percentage of the initial dry weight.

ISRM (1981) (24) and Geological Society of London (1970) scales (25) on the grounds of the mechanical test results. Similarly, they meet the requirements for use both as dimensional rock and outdoor paving for normal or intense pedestrian traffic set out in the Technological Building Standards (Spanish initials, NTE) issued by the Spanish Ministry of Interior Development's Directorate General of Building Architecture and Technology. Their high freezing resistance, in turn, makes them suitable for use in cold climates.

The lower variability in the test results for Alcañiz sandstone is a result of its higher compositional uniformity and greater quarrying depth.

This stone's better behaviour in the salt crystallization test is due to the geometry of its pore network, which provides for quicker water absorption and desorption and less water retention after drying at atmospheric temperature than the Uncastillo and Ayerbe materials. In all three sandstones, the mechanism observed in salt crystallization-induced alteration was granular disintegration. The use of protection treatments would be recommendable to improve the durability of these materials (particularly the Uncastillo and Ayerbe sandstones) (26).

\section{ACKNOWLEDGEMENTS}

The authors are grateful to the Regional Department of Industry of the Government of Aragon for providing the Uncastillo, Ayerbe and Alcañiz geomechanical data and 
una beca predoctoral al primero de los autores (O.B.) Ref. B044,2004, gracias a la cual se ha realizado parte de este trabajo, y a la empresa Olnasa S.L. por suministrarnos el material. for the post-graduate grant awarded to the first author (O.B.) under Ref. B044,2004, thanks to which part of this study could be conducted. Material for this survey was supplied by OInasa S.L.

\section{BIBLIOGRAFÍA / BIBLIOGRAPHY}

(1) Arenas, C.: Sedimentación y paleogeografía del Terciario del margen pirenaico y sector central de la cuenca del Ebro (zona aragonesa occidental), Tesis doctoral, Universidad de Zaragoza. Inédita (1993).

(2) Esbert, R., Marcos, R., Ordaz, J., Montoto, M., Suárez, L., Ruiz de Argandeña, V., Calleja, L., Alonso, F. J. y Rodríguez-Rey, A.: "Petrografía, propiedades físicas y durabilidad de algunas rocas utilizadas en el patrimonio monumental de Catalunya, España", Mater. Construcc., vol. 39, no 214 (1989), pp. 37-47.

(3) Andaluz, N., Gisbert, J., Marin, C. y Delgado, S.: "Propuesta de clasificación petrográfica de las areniscas terciarias del valle del Ebro", Geogaceta, vol. 24 (1988), pp. 19-22.

(4) Andaluz, N., Marin, C., Gisbert, J. y Recuenco, J.: "Petrophysic of Tertiary sandstone in eastern Aragon (Ebro basin, Spain)", Quarry laboratory - monument, International congress-Pavia, 2000.

(5) Puigdefábregas, T.: La sedimentación molásica en la cuenca de Jaca, Monografías del Instituto de Estudios Pirenaicos, nº $104,1975$.

(6) Quitantes, J.: Estudio sedimentológico y estratigráfico del Terciario continental de los monegros, Institución Fernando el Católico, CSIC Zaragoza, 1978, p. 207.

(7) Poli, T., Toniolo, L. y Chiantore, O.: "The protection of different marbles with two partially fluorinated acrylic copolymers", Materials Science \& Processing, vol. 79, no 2 (2004), pp. 347-351.

(8) Munsell: Munsell soil color charts, Munsell products, Baltimore, Maryland, 1976.

(9) Norma UNE 12372: "Métodos de ensayo para piedra natural. Determinación de la resistencia a la flexión bajo carga concentrada", 1999.

(10) Norma UNE-EN 1926: "Métodos de ensayo para piedra natural. Determinación de la resistencia a la compresión", 1999.

(11) Norma UNE-EN 1936: "Métodos de ensayo para piedra natural. Determinación de la densidad real y aparente y de la porosidad abierta y total", 1999.

(12) Norma UNE-EN 1341: "Baldosas de piedra natural para uso como pavimento exterior. Requisitos y métodos de ensayo".

(13) Norma UNE-EN 12407: "Métodos de ensayo para piedra natural. Estudio petrográfico", 2001.

(14) Norma UNE-EN 13755: "Métodos de ensayo para piedra natural. Determinación de la absorción de agua a presión atmosférica", 2002.

(15) Norma ASTM D 2240: "Standard Test Methods for rubber property - durometer hardness", vol. 09.01 USA, 1992.

(16) Normal Comision 25-PEM Protección y erosión de monumentos: Ensayo no II. Dilatación lineal por absorción de agua, 1980.

(17) Normal 11/85 oggetto- "assorbimento d'acqua per capillaritè - coefficiente di assorbimento capillare", CNR-ICR, Roma.

(18) Schön, J. H.: Physical properties of rocks: Fundamentals and principles of petrophysics. Pergamon, Nueva York, 1996, p. 583.

(19) Norma UNE 67-028-97-EX.: "Ladrillos cerámicos de arcilla cocida. Ensayo de heladicidad".

(20) Normal Comision 25-PEM Protección y erosión de monumentos: Ensayo nV.b.: "Cristalización por inmersión total para piedra tratada", 1980.

(21) Pettijohn, F. J., Potter, P. E. y Siever, R.: Sand and sandstone, Springer Verlag, New Cork, 1987, p. 553.

(22) Beard, D.C. y Weyl, P. K.: Diagenesis of sandstone, AAPG reprint series no 20, 1997.

(23) Fort, R., Bernabéu, A., García del Cura, M. A., López de Azcona, M. C., Ordóñez, S. y Mingarro, F.: "La piedra de Novelda: una roca muy utilizada en el patrimonio arquitectónico", Mater. Construcc. (2002), no 266, pp. 19-33.

(24) ISRM: ISRM (Internacional Society for Rock Mechanics), 1981, en E. T. Brown (ed.): "ISRM Suggested method: Rock characterization, testing and monitoring", Pergamon press, Londres.

(25) González Vallejo, L.: Ingeniería Geológica, Pearson Prentica Hall, 2003, p. 715.

(26) Buj, O. y Gisbert, J.: "Evaluation of three consildant in Miocene sandstones of the Ebro basin. Heritage, Weathering and conservation", en R. Fort, M. Álvarez de Buergo, M. Gomez-Heras y C. Vazquez-Calvo (eds.): vol. 2, 2006, pp. 741-748. 